\title{
Identification and Pathogenicity of Rhizoctonia spp. Isolated from Apple Roots and Orchard Soils
}

\author{
Mark Mazzola
}

USDA Agricultural Research Service, Tree Fruit Research Laboratory, 1104 N. Western Avenue, Wenatchee, WA 98801. Accepted for publication 11 March 1997.

\begin{abstract}
Mazzola, M. 1997. Identification and pathogenicity of Rhizoctonia spp. isolated from apple roots and orchard soils. Phytopathology 87:582-587.

Rhizoctonia spp. were isolated from the roots of apple trees and associated soil collected in orchards located near Moxee, Quincy, East Wenatchee, and Wenatchee, WA. The anastomosis groups (AGs) of Rhizoctonia spp. isolated from apple were determined by hyphal anastomosis with tester strains on $2 \%$ water agar and, where warranted, sequence analysis of the rDNA internal transcribed spacer region and restriction analysis of an amplified fragment from the 28S ribosomal RNA gene were used to corroborate these identifications. The dominant AG of $R$. solani isolated from the Moxee and East Wenatchee orchards were AG 5 and

AG 6, respectively. Binucleate Rhizoctonia spp. were recovered from apple roots at three of four orchards surveyed and included isolates of AG-A, -G, -I, -J, and -Q. In artificial inoculations, isolates of $R$. solani AG 5 and AG 6 caused extensive root rot and death of 2- to 20-week-old apple transplants, providing evidence that isolates of $R$. solani AG 6 can be highly virulent and do not merely exist as saprophytes. The effect of binucleate Rhizoctonia spp. on growth of apple seedlings was isolatedependent and ranged from growth enhancement to severe root rot. $R$. solani AG 5 and AG 6 were isolated from stunted trees, but not healthy trees, in an orchard near Moxee, WA, that exhibited severe symptoms of apple replant disease, suggesting that $R$. solani may have a role in this disease complex.
\end{abstract}

Rhizoctonia solani is a ubiquitous soilborne pathogen capable of causing severe economic damage to a wide variety of plant species. Many tree species are susceptible to $R$. solani (9), and this pathogen is of primary importance in seedbeds and nurseries, where it is a common cause of damping-off and root rot of seedlings. In addition, $R$. solani has been isolated from roots of trees grown in landscape environments and orchards, but has not been shown to be an important root pathogen of older trees. There are few reports of this fungus causing diseases of orchard trees $(2,13,22)$. Although $R$. solani has been reported to cause a disease on apple $(1,7,8)$, the study by Burr et al. (2) of a severe root rot of apple seedlings in commercial nurseries in New York appears to be the only study to document the potential economic significance of this pathogen on apple.

$R$. solani is a taxonomic species composed of morphologically similar fungi isolated by hyphal incompatibility into at least 12 anastomosis groups (AGs). There are no reports concerning the AGs of $R$. solani that are capable of infecting apple. Likewise, the relative importance of different AGs in causing disease on apple, or the possible involvement of other species of Rhizoctonia in root rot of apple either in nursery or orchard environments, has yet to be examined. Given the variability among species and AGs of Rhizoctonia in many significant characteristics, including sensitivity to chemical $(15,27)$ and biological control agents $(14,20)$, successful management of Rhizoctonia root rot of apple will require a more complete understanding of the causal fungus. The objective of this study was to characterize isolates of Rhizoctonia spp. associated with apple roots and investigate the possible role of Rhizoctonia spp. in a root rot disease observed in new and established apple orchards in Washington state. A preliminary report of this work has been published (19).

Corresponding author: M. Mazzola; E-mail address: mazzola@tfrl.ars.usda.gov

Publication no. P-1997-0328-01R

This article is in the public domain and not copyrightable. It may be freely reprinted with customary crediting of the source. The American Phytopathological Society, 1997.

\section{MATERIALS AND METHODS}

Isolation of Rhizoctonia spp. Soil and root samples were collected from the Washington State University/USDA-ARS Columbia View Experimental Orchard (CV orchard), located $20 \mathrm{~km}$ north of East Wenatchee, WA; the Wenatchee Valley College Experimental Orchard (WVC orchard), located $1.5 \mathrm{~km}$ north of Wenatchee, WA; and commercial orchards near Moxee (DR orchard) and Quincy (CW orchard), WA. The study site at the DR orchard was prepared for renovation in November 1994 by removal of trees and burning of slash on site. The site was not fumigated prior to replanting the site in April 1995 with five rows (6.1 $\times 2.4-\mathrm{m}$ spacing) of the apple cultivar Gala on M26 rootstock, with four rows planted directly into the rows of the previous orchard. The fifth row was established on the west edge of the block in soil that had not previously been planted to apple. Soil and root samples were obtained from a 5-year-old planting of 'Braeburn' on M7 rootstock and a 7-year-old planting of 'Gala' on M9 rootstock at the CW and WVC orchards, respectively. Samples were collected from a 4-year-old planting containing various scion cultivars on M26 rootstock, a 7-year-old planting of 'Red Delicious' on M111 rootstock, and a 26-year-old planting of 'Red Delicious' on seedling rootstock at the $\mathrm{CV}$ orchard.

Soil and root samples were randomly collected from 30 individual trees at the DR orchard site on 12 September and 9 November 1995 and 10 January 1996, and 10 sites within each sampled block at the CV, CW, and WVC orchards between 21 September 1995 and 30 May 1996. Soil samples (approximately $750 \mathrm{~cm}^{3}$ ) were collected from within the root zone at a depth of 10 to $30 \mathrm{~cm}$ below the surface.

Isolation of Rhizoctonia spp. from field-infected apple tissue was conducted by washing roots with tap water to remove adhering soil particles and plating root segments $(0.5$ to $1.0 \mathrm{~cm}$ in length) on $1.5 \%$ water agar amended with kanamycin sulfate (75 $\mu \mathrm{g} / \mathrm{ml})$ or ampicillin $(100 \mu \mathrm{g} / \mathrm{ml})$. Baiting methods were used to isolate Rhizoctonia spp. from orchard soils. Apple seeds ('Gala') were surface-sterilized in a $10 \%$ solution of commercial bleach (5.25\% sodium hypochlorite) and rinsed for $30 \mathrm{~min}$ under running 
tap water. Seeds were dusted with captan 50WP and stratified for germination by placing seed in a plastic bag with moistened paper towels at $4^{\circ} \mathrm{C}$ for 6 to 8 weeks. Germinated seeds were sown into a sterile peat moss/perlite mix and incubated at $24^{\circ} \mathrm{C}$ with a $12-\mathrm{h}$ photoperiod. Conical plastic tubes $(20.5 \times 4 \mathrm{~cm}$ [top diameter]; Stuewe \& Sons, Inc., Corvallis, OR) were filled with a $50-\mathrm{cm}^{3}$ layer of vermiculite and topped with a $50-\mathrm{cm}^{3}$ layer of orchard soil. One 21-day-old apple seedling was transplanted into each tube, with a total of seven tubes planted for each soil sample. Seedlings were grown in controlled environment growth chambers at $18^{\circ} \mathrm{C}$ with a 12 -h photoperiod. Seedlings were harvested after 14 days, and roots were washed under a high pressure stream of water. Excised root segments were plated onto water agar as described above and incubated at 20 to $23^{\circ} \mathrm{C}$ for $72 \mathrm{~h}$, and hyphae emanating from root segments were examined using a light microscope (Olympus BH2 series; Olympus Optical Co. Ltd., Japan). Rhizoctonia-like hyphae were transferred to fresh $1 / 5$-strength potato dextrose agar (PDA) (Difco Laboratories, Detroit) medium amended with ampicillin $(100 \mu \mathrm{g} / \mathrm{ml})$ and stored at $4^{\circ} \mathrm{C}$.

Anastomosis typing of Rhizoctonia spp. isolates. Nuclear condition of isolates of Rhizoctonia spp. was determined by distributing a wetting solution (Tween 20) over mycelium on a culture plate, staining hyphae with $0.5 \%$ aniline blue in lactophenol (10), and observing hyphae microscopically. Anastomosis typing of Rhizoctonia spp. isolates was conducted on $2 \%$ water agar in petri dishes (26), with each unknown isolate paired with an isolate of known anastomosis grouping (Table 1). Confirmation of genetic affinities for some isolates of $R$. solani was conducted by comparison of the nucleotide sequences of the internal transcribed spacer (ITS) 1 region from tester strains with that of unknown isolates. The ITS nucleotide sequences for isolates of $R$. solani AGs 1 to 6 and 8 were determined previously (21). Genomic DNA was extracted from each isolate of Rhizoctonia as described previously (21). The primers ITS 1 and ITS 4 (32) were used in polymerase chain reaction $(\mathrm{PCR})$ reactions with genomic DNA from isolates of Rhizoctonia to amplify a region that spans from the $3^{\prime}$ end of the $18 \mathrm{~S}$ rRNA gene to the $5^{\prime}$ end of the $28 \mathrm{~S}$ rRNA gene and includes the 5.8S rRNA gene and the two ITS regions (ITS 1 and ITS 2). Amplifications of the ITS sequence were conducted in a DNA Thermal Cycler 480 (Perkin-Elmer Corp., Norwalk, CT) using reaction conditions described by Mazzola et al. (21). The resulting PCR products were cloned into the vector pCRII (TA cloning kit; Invitrogen Corp., San Diego, CA) and transformed into Escherichia coli INV $\alpha \mathrm{F}^{\prime}$ using the protocol provided by the manufacturer. The ITS 1 region from Rhizoctonia spp. was sequenced using an ABI Prism 377 automated DNA sequencer (Perkin-Elmer Corp.). Restriction analysis of the 28S rRNA gene was conducted to corroborate results obtained from anastomosis tests on water agar and sequencing of the ITS region that indicated that certain isolates of $R$. solani from apple belonged to AG 6. A portion of the $28 \mathrm{~S}$ rRNA gene was amplified from genomic DNA of isolates of Rhizoctonia using the primers LR0R and LR7 (30) in PCR reactions. The reaction conditions were those described by Cubeta et al. (5) for amplification of this region from binucleate Rhizoctonia spp. The amplified PCR products were digested with HhaI, HpaII, or TaqI, and DNA fragments were separated in a $1.5 \%$ agarose gel in Tris-borate-EDTA buffer. The gel was stained with ethidium bromide, and the DNA fragments were viewed using a UV transilluminator.

Pathogenicity assays. The ability of isolates of Rhizoctonia to cause root rot of apple were determined in assays using transplants of varying age. Seeds of the cultivar Gala were sown in plastic flats containing pasteurized (exposed to steam at $97^{\circ} \mathrm{C}$ for $90 \mathrm{~min}$ ) peat moss/perlite growth medium and placed in growth chambers at $24^{\circ} \mathrm{C}$ with a 12 -h photoperiod for up to 21 days. When larger plants were required, 21-day-old seedlings were transplanted into $16-\mathrm{cm}$-diameter plastic pots containing pasteurized Burch sandy loam from the $\mathrm{CV}$ orchard and grown in the greenhouse at $20^{\circ} \mathrm{C}$ without supplemental lighting. Pathogenicity assays were performed in natural and pasteurized Willis silt loam (WSL) collected from the DR orchard. Inoculum of Rhizoctonia was prepared by growing isolates individually in 500-ml Erlenmeyer flasks containing $250 \mathrm{ml}$ of oat bran and $80 \mathrm{ml}$ of distilled water. The flasks were sterilized on two consecutive days for 90 min and inoculated with a culture of Rhizoctonia growing on $1 / 5$ strength PDA. Flasks were incubated at $20^{\circ} \mathrm{C}$ for 14 days, and then inoculum was air-dried under a laminar flow hood. Oat bran inoculum was added to soil at a rate of $0.25 \%(\mathrm{wt} / \mathrm{wt})$, and soils were planted after $24 \mathrm{~h}$ of incubation at 20 to $23^{\circ} \mathrm{C}$. Assays with 2- and 3-week-old seedlings were conducted in conetainers, with a single seedling planted per tube and 14 replicates per isolate of Rhizoctonia. Pathogenicity assays using 7- and 12-week-old trees were performed in 16-cm-diameter plastic pots with three seedlings per pot, and each treatment was replicated four times. Assays conducted with 20-week-old seedlings were performed in 16$\mathrm{cm}$-diameter pots with one tree per pot, and each treatment was replicated seven times. In each assay, seedlings grown in pasteurized or natural soil without added inoculum of Rhizoctonia spp. served as controls. Plants were placed in environmental growth chambers at $18^{\circ} \mathrm{C}$ with a $12-\mathrm{h}$ photoperiod. Assays using 2- or 3week-old seedlings were harvested after 2 weeks, and those conducted with 7- and 12-week-old trees were harvested 3 and 6 weeks after transplanting, respectively. Shoot and root weight were determined at harvest. When 20 -week-old transplants were used in

TABLE 1. Anastomosis group (AG) and origin of tester isolates of Rhizoctonia spp. used in this study

\begin{tabular}{|c|c|c|c|}
\hline Isolate & AG & Host or habitat & Source ${ }^{a}$ \\
\hline \multicolumn{4}{|c|}{ Rhizoctonia solani } \\
\hline R. shi-2 & $1-1 B$ & $\ldots{ }^{b}$ & Cook \\
\hline $\mathrm{F}-2$ & $1-1 \mathrm{C}$ & $\ldots$ & Cook \\
\hline $\mathrm{H}-24$ & $2-1$ & $\ldots$ & Cook \\
\hline $455-11$ & $2-2$ & $\ldots$ & Cook \\
\hline ST-9 & 3 & $\ldots$ & Cook \\
\hline $6-3-6$ & 4 & Triticum aestivum & Cook \\
\hline $2-5-5$ & 4 & T. aestivum & Cook \\
\hline D-1 & 5 & T. aestivum & Cook \\
\hline SO-2-1 & 6 & $\ldots$ & Cook \\
\hline TSH1-1 & 6 & $\ldots$ & Cook \\
\hline C-1 & 8 & Hordeum vulgare & Cook \\
\hline $2-10-2$ & 10 & H. vulgare & Cook \\
\hline \multicolumn{4}{|c|}{ Binucleate Rhizoctonia spp. } \\
\hline C-662 & A & Soil & Cubeta \\
\hline $\mathrm{BN} 4$ & A & Soil & Cubeta \\
\hline C-455 & $\mathrm{Bb}$ & Oryzae sativa & Cubeta \\
\hline SIR-2 & $\mathrm{B}(\mathrm{o})$ & Ipomoea batatas & Cubeta \\
\hline $70 \mathrm{~B}$ & $\mathrm{C}$ & Soil & Cubeta \\
\hline C-610 & $\mathrm{D}$ & $\ldots$ & Cubeta \\
\hline BN1 & $\mathrm{D}$ & Agrostis sp. & Cubeta \\
\hline $1-1 b-9$ & $\mathrm{E}$ & T. aestivum & Cook \\
\hline BN31 & $\mathrm{E}$ & Arachis hypogaea & Cubeta \\
\hline SIR-1 & $\mathrm{F}$ & I. batatas & Cubeta \\
\hline BN38 & $\mathrm{F}$ & Glycine $\max$ & Cubeta \\
\hline C-653 & $\mathrm{G}$ & $\ldots$ & Cubeta \\
\hline STC-9 & $\mathrm{H}$ & Soil & Cubeta \\
\hline AV-2 & I & Artemesia sp. & Cook \\
\hline 184 & $\mathrm{~J}$ & $\ldots$ & Cubeta \\
\hline FA52909 & $\mathrm{K}$ & $\ldots$ & Cubeta \\
\hline 76146 & $\mathrm{~L}$ & $\ldots$ & Caesar \\
\hline $\mathrm{TC} 1$ & $\mathrm{~N}$ & $\ldots$ & Caesar \\
\hline 76150 & $\mathrm{P}$ & $\ldots$ & Caesar \\
\hline $\mathrm{C}-620$ & Q & Soil & Cubeta \\
\hline $\mathrm{TC} 2$ & $\mathrm{R}$ & $\ldots$ & Caesar \\
\hline BN37 & $\mathrm{R}$ & Cucumis sativum & Cubeta \\
\hline TC3 & $\mathrm{S}$ & $\ldots$ & Caesar \\
\hline $\mathrm{BN} 22$ & $\mathrm{~S}$ & Pittosporum sp. & Cubeta \\
\hline
\end{tabular}

a A. J. Caesar, USDA/ARS, 1500 N. Central Ave., Sidney, MT; R. J. Cook, USDA/ARS, Washington State University, Pullman; and M. Cubeta, University of North Carolina, Vernon James Center, Plymouth.

b Unknown. 
pathogenicity assays, the weight of each tree was determined prior to planting and again after 6 weeks. The increase in plant biomass of trees grown in soil infested with $R$. solani was compared with that of trees grown in noninfested soil.

\section{RESULTS}

Isolation and identification of Rhizoctonia spp. from apple. A total of 87 isolates of Rhizoctonia were recovered from apple roots or baited from orchard soil. All isolates came from different field-infected trees or different seedlings planted in orchard soil samples. Of these, 32 isolates were multinucleate and 55 were binucleate. The composition of Rhizoctonia isolates recovered from apple roots and associated soil varied among the surveyed orchards. $R$. solani was isolated from the DR and CV orchards, but not the WVC and CW orchards. Based on hyphal anastomosis with known tester isolates, all isolates of $R$. solani from the $\mathrm{CV}$ orchard were classified as AG 6, while the population recovered from the DR orchard consisted of 18 isolates belonging to AG 5

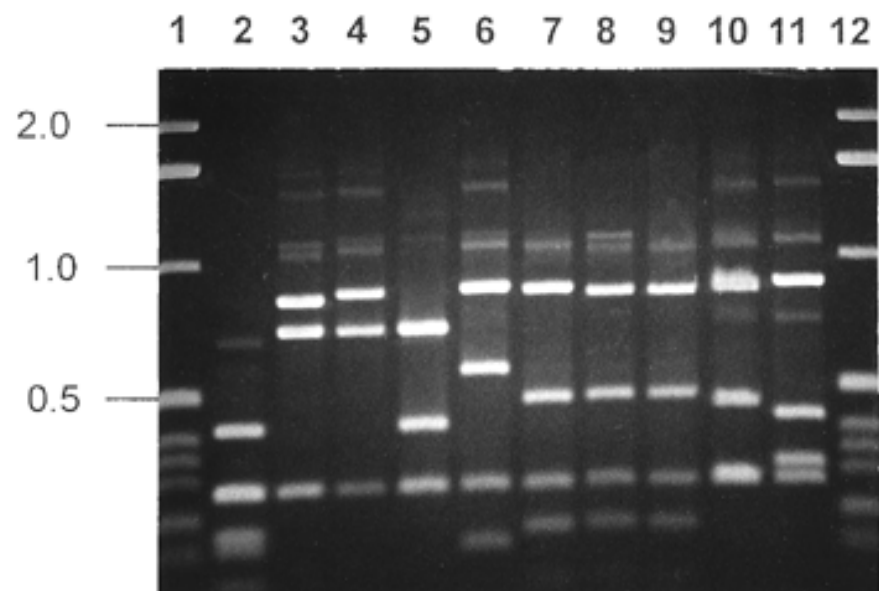

Fig. 1. Restriction enzyme digestion (HpaII) of a polymerase chain reactionamplified portion of 25S rDNA using the primers LR0R and LR7 and purified DNA from isolates of Rhizoctonia solani. Lanes 1 and 12, 1-kb DNA ladder; lane 2, AG 1 isolate F-2; lane 3, AG 2 isolate $\mathrm{H}-24$; lane 4, AG 3 isolate ST-9; lane 5, AG 4 isolate 6-3-6; lane 6, AG 5 isolate D-1; lane 7, AG 6 isolate CV-B; lane 8, AG 6 isolate CV-D; lane 9, AG 6 isolate TSH1-1; lane 10, AG 8 isolate C-1; and lane 11, AG BI isolate Ts2-4.

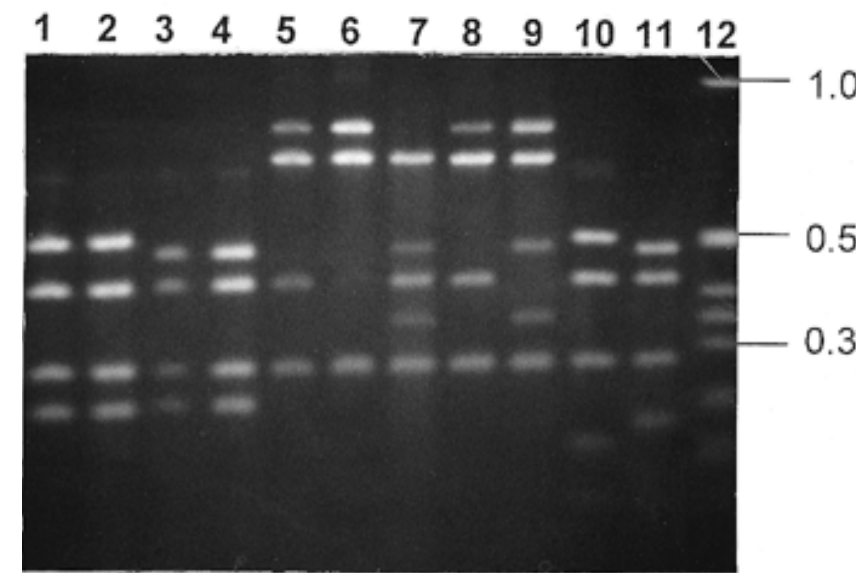

Fig. 2. Restriction enzyme digestion (HpaII) of a polymerase chain reactionamplified portion of $25 \mathrm{~S}$ rDNA using the primers LR0R and LR7 and purified DNA from isolates of binucleate Rhizoctonia spp. Lane 1, AG-A isolate C-662; lane 2, AG-A isolate B21-3; lane 3, AG-G isolate C-653; lane 4, AG-G isolate E39-2; lane 5, AG-I isolate AV-2; lane 6, AG-I isolate WVC-8; lane 7, AG-I isolate CW1-7; lane 8, AG-J isolate 184; lane 9, AG-J isolate CW2-2; lane 10, AG-Q isolate C-620; lane 11, AG-Q isolate E3-2; and lane 12, 1-kb DNA ladder. and three isolates identified as AG 6. The ITS 1 nucleotide sequence of isolate E22-4 from the DR orchard possessed $98 \%$ sequence identity with the corresponding fragment from $R$. solani AG 5 tester isolate D-1, while isolate CV-B had $92 \%$ sequence identity in the same region of DNA with $R$. solani AG 6 tester isolates SO-2-1 and TSH1-1. The restriction pattern obtained after digestion of the amplified 28S rRNA region from isolates CV-B and CV-D with either TaqI or HhaI (data not shown) was identical to that of isolate TSH1-1, but also was the same as that observed for isolates of AG 8 and AG BI. The restriction pattern obtained with HpaII for isolates of AG 6 was distinctive and allowed for the separation of isolates of AG 6 from AG 8 and AG BI isolates (Fig. 1).

Binucleate Rhizoctonia spp. were isolated from apple roots or soil obtained from the CW, DR, and WVC orchards. Restriction analysis of the rDNA fragment indicated that the population of binucleate Rhizoctonia spp. recovered from both the DR and CW orchards was composed of at least five different groups, but that all binucleate Rhizoctonia isolates from the WVC orchard represented a single group. Based on anastomosis with tester isolates, all binucleate Rhizoctonia spp. from the WVC orchard belonged to AG-I, the collection from the $\mathrm{CW}$ orchard contained isolates of AG-G, -I, and -J, and those from the DR orchard were identified as $\mathrm{AG}-\mathrm{A},-\mathrm{G}$, and -Q. Restriction patterns obtained by HpaII digestion of the amplified 28S rDNA fragment from AG-A and AG-G isolates from apple were similar to those of tester isolates, but those of AG-I, -J, and -Q were different from the tester strains (Fig. 2). Polymorphisms were also observed in the restriction patterns between AG-I isolates from the WVC orchard and those from the $\mathrm{CW}$ orchard (Fig. 2). Isolates from the $\mathrm{DR}$ and $\mathrm{CW}$ orchards representing at least two different groups could not be identified to an AG based on restriction analysis of the rDNA fragment or anastomosis with the known tester isolates used in this study. Based on restriction fragment length polymorphisms, one group from the DR orchard consisted of isolates B41-2, C41-1,

TABLE 2. Effect of Rhizoctonia spp. isolated from apple trees at the $\mathrm{DR}^{\mathrm{a}}$ and $\mathrm{CV}^{\mathrm{b}}$ orchards on growth of 3-week-old apple ('Gala') seedling transplants in natural Willis silt loam

\begin{tabular}{|c|c|c|c|c|c|}
\hline \multirow[b]{2}{*}{ Isolate } & \multirow[b]{2}{*}{$\mathrm{AG}^{\mathrm{c}}$} & \multicolumn{2}{|c|}{ Trial 1} & \multicolumn{2}{|c|}{ Trial 2} \\
\hline & & $\begin{array}{l}\text { Shoot wt } \\
\quad(\mathrm{mg})\end{array}$ & $\begin{array}{l}\text { Root wt } \\
\quad(\mathrm{mg})\end{array}$ & $\begin{array}{l}\text { Shoot wt } \\
(\mathrm{mg})\end{array}$ & $\begin{array}{c}\text { Root wt } \\
\text { (mg) }\end{array}$ \\
\hline Control & & 433 & 248 & 680 & 266 \\
\hline C13-2 & A & 433 & 298 & 516 & 227 \\
\hline B21-3 & A & 365 & 235 & 561 & 336 \\
\hline B6-1 & $\mathrm{G}$ & 396 & 235 & 538 & 220 \\
\hline B6-2 & $\mathrm{G}$ & 387 & 195 & 592 & 298 \\
\hline B46-1 & $\mathrm{G}$ & 394 & 191 & 514 & 310 \\
\hline E39-2 & $\mathrm{G}$ & 361 & 160 & 412 & 161 \\
\hline E3-2 & $\mathrm{Q}$ & 200 & 112 & 425 & 144 \\
\hline B41-2 & UK1 & 436 & 264 & 512 & 271 \\
\hline C41-1 & UK1 & 359 & 177 & 481 & 230 \\
\hline C46-1 & UK1 & 451 & 278 & 557 & 229 \\
\hline D44-2 & $\mathrm{UK} 2$ & 481 & 369 & 574 & 358 \\
\hline D44-3 & UK2 & 461 & 267 & 613 & 257 \\
\hline E44-1 & UK2 & 441 & 329 & 626 & 349 \\
\hline B20-1 & 5 & 246 & 86 & 494 & 169 \\
\hline B32-1 & 5 & 332 & 158 & 473 & 186 \\
\hline B41-1 & 5 & 175 & 126 & 408 & 123 \\
\hline E22-4 & 5 & 298 & 127 & 352 & 142 \\
\hline $5-103$ & 5 & 292 & 131 & 459 & 113 \\
\hline $5-104$ & 5 & 303 & 103 & 359 & 98 \\
\hline CV-B & 6 & 298 & 122 & 211 & 59 \\
\hline D20-1 & 6 & 246 & 86 & 187 & 25 \\
\hline $\operatorname{LSD}(P=0.05)$ & & 94 & 79 & 132 & 77 \\
\hline
\end{tabular}

a Commercial orchard near Moxee, WA.

b Washington State University/USDA-ARS Columbia View Experimental Orchard, located $20 \mathrm{~km}$ north of East Wenatchee, WA.

c UK signifies that the anastomosis group (AG) is not known, but all isolates with the same number following this designation belong to the same AG based on anastomosis tests on water agar. 
and C46-1, and a second group contained isolates D44-2, D44-3, and E44-1. The unclassified groups from the CW orchard consisted of isolates CW1-8 and CW2-1, and a second group contained isolates CW1-1, CW1-2, and CW1-6.

Pathogenicity of Rhizoctonia spp. on apple. The ability of Rhizoctonia spp. to cause root rot of apple was evaluated using 2-, $3-, 7-, 12-$, or 20-week-old transplants. Initial assays were conducted using 2-week-old apple seedlings that were transplanted into pasteurized WSL infested with a single isolate of $R$. solani AG 5 or $R$. solani AG 6 . The isolates of $R$. solani AG 5 used in this experiment were E22-1, E22-2, E22-3, and E22-4, while those of AG 6 were $\mathrm{CV}-\mathrm{A}, \mathrm{CV}-\mathrm{B}, \mathrm{CV}-\mathrm{C}$, and CV-D. These isolates were chosen for evaluation as they represented the dominant species of Rhizoctonia isolated from the DR and CV orchards, respectively. Extensive root rot of seedlings was apparent within $72 \mathrm{~h}$, and all plants grown in infested soil had wilted within 7 days of transplanting, while those seedlings transplanted into noninfested soil exhibited no symptoms of root rot or wilt. Root segments from three seedlings for each soil treatment were plated onto $1.5 \%$ water agar amended with ampicillin. $R$. solani was reisolated from each seedling grown in artificially infested soil, but was not recovered from seedlings grown in noninfested pasteurized soil.

Of the 87 isolates of Rhizoctonia from apple roots or orchard soil, 34 isolates were evaluated in pathogenicity assays using 3week-old apple seedlings in natural WSL. Isolates evaluated in these assays were chosen so that all known AGs, as well as groups that were genetically distinct but could not be placed into an AG, were represented. Eleven of the 34 isolates of Rhizoctonia caused root rot of apple, resulting in significant reductions in both shoot and root biomass (Table 2). With the exception of isolate E39-2, all isolates of Rhizoctonia that were pathogenic to apple also caused seedling mortality, which was $50 \%$ or greater in soil infested with isolate B20-1, CV-B, D20-1, E3-2, E22-4, 5-103, or 5-104. Isolates of Rhizoctonia that were pathogenic on apple were identified as $R$. solani AG 5 or AG 6, except isolates E3-2, E39-2, and WVC-8 (Table 3), which are binucleate Rhizoctonia spp. belonging to AG-Q, -G, and -I, respectively. Isolates D44-2 and E44-1 significantly enhanced root biomass of seedlings grown in WSL (Table 2). The remaining isolates of binucleate Rhizoctonia spp. had no apparent effect on the growth of 3-week-old apple seedlings (Tables 2 and 3).

TABLE 3. Effect of Rhizoctonia spp. isolated from apple trees at the $\mathrm{CW}^{\mathrm{a}}$ and $\mathrm{WVC}^{\mathrm{b}}$ orchards on growth of 3-week-old apple ('Gala') seedling transplants in natural Willis silt loam

\begin{tabular}{lcccccc}
\hline & & \multicolumn{2}{c}{ Trial 1 } & & \multicolumn{2}{c}{ Trial 2 } \\
\cline { 3 - 4 } \cline { 6 - 7 } Isolate & $\mathrm{AG}^{\mathrm{c}}$ & $\begin{array}{c}\text { Shoot } \mathrm{wt} \\
(\mathrm{mg})\end{array}$ & $\begin{array}{c}\text { Root } \mathrm{wt} \\
(\mathrm{mg})\end{array}$ & & $\begin{array}{c}\text { Shoot wt } \\
(\mathrm{mg})\end{array}$ & $\begin{array}{c}\text { Root wt } \\
(\mathrm{mg})\end{array}$ \\
\hline Control & & 423 & 205 & & 425 & 147 \\
CW-1 & $\mathrm{G}$ & 348 & 166 & & 425 & 121 \\
CW-2 & $\mathrm{G}$ & 345 & 151 & & 342 & 125 \\
CW1-7 & $\mathrm{I}$ & 332 & 127 & & 470 & 134 \\
CW1-9 & $\mathrm{I}$ & 308 & 131 & & 414 & 127 \\
CW1-10 & $\mathrm{I}$ & 383 & 162 & & 429 & 147 \\
CW3-1 & $\mathrm{I}$ & 347 & 139 & & 498 & 159 \\
WVC-8 & $\mathrm{I}$ & 206 & 58 & & 263 & 66 \\
CW2-2 & $\mathrm{J}$ & 300 & 129 & & 481 & 167 \\
CW1-1 & UK3 & 328 & 153 & & 419 & 152 \\
CW1-2 & UK3 & 309 & 135 & & 434 & 165 \\
CW1-6 & UK3 & 325 & 137 & & 453 & 174 \\
CW1-8 & UK4 & 348 & 178 & & 401 & 133 \\
CW2-1 & UK4 & 310 & 151 & & 424 & 137 \\
LSD $(P=0.05)$ & & 163 & 117 & 107 & 71 \\
\hline
\end{tabular}

a Commercial orchard near Quincy, WA.

${ }^{\mathrm{b}}$ Wenatchee Valley College Experimental Orchard, located $1.5 \mathrm{~km}$ north of Wenatchee, WA.

${ }^{\mathrm{c}}$ UK signifies that the anastomosis group (AG) is not known, but all isolates with the same number following this designation belong to the same AG based on anastomosis tests on water agar.
Among the isolates of Rhizoctonia spp. examined, $R$. solani AG 5 isolates E22-4 and 5-104, and $R$. solani AG 6 isolate CV-B, consistently caused severe damage to apple seedlings that were 14 or 21 days old at the time of transplanting into infested soil. Therefore, these isolates were used in assays to determine the susceptibility of 7-week-old apple transplants to $R$. solani. In the absence of added inoculum of $R$. solani, shoot and root weights were significantly $(P \leq 0.001)$ larger for plants grown in pasteurized than in natural DR orchard soil (Table 4). Both $R$. solani AG 5 and $R$. solani AG 6 caused root rot of 7-week-old apple seedlings in pasteurized soil, resulting in significant reductions in root and shoot weight (Table 4). In natural soil, all three isolates of $R$. solani caused root rot of apple, resulting in lower root biomass, but only isolates CV-B and 5-104 caused a significant reduction in shoot weight. Seedling mortality was 25 and $42 \%$ for plants grown in natural and pasteurized soil, respectively, infested with $R$. sola$n i$, but seedling mortality was not observed in noninfested soil.

Pasteurization had a significant $(P \leq 0.001)$ positive effect on growth of 12-week-old apple transplants in noninfested soil from the DR orchard (Table 5). In pasteurized soil, all three isolates of $R$. solani significantly reduced the biomass of apple transplants. In natural soil, isolates CV-B and 5-104 each caused root rot of 12week-old transplants, but isolate E22-4 did not cause a significant reduction in plant biomass. All transplants grown in noninfested soil or soil infested with isolate E22-4 were alive at harvest, but mortality was observed for 16 and $25 \%$ of transplants grown in soil infested with isolates CV-B and 5-104, respectively.

Twenty-week-old apple trees transplanted into $R$. solani-infested soil were harvested 6 weeks after initial exposure to the pathogen. The increase in plant biomass during the 6-week period for trees grown in soil infested with $R$. solani 5-104 and CV-B was 31 and $15 \%$, respectively, of that obtained in noninfested soil, and both isolates caused tree mortality.

\section{DISCUSSION}

Isolates of Rhizoctonia spp. were recovered from the roots of recently established orchard transplants exhibiting symptoms of apple replant disease, from mature apple trees that ranged from 4 to 26 years of age, and associated orchard soil. The collection of Rhizoctonia spp. obtained from the surveyed orchards consisted of a diverse group of multinucleate and binucleate species. Isolates of $R$. solani AG 5 and AG 6 were recovered from field-infected trees in the DR orchard, while all isolates of $R$. solani from the

TABLE 4. Effect of Rhizoctonia solani anastomosis group (AG) 5 isolates E22-4 and 5-104 and AG 6 isolate CV-B on growth of 7-week-old apple ('Gala') transplants

\begin{tabular}{lccccc}
\hline & \multicolumn{2}{c}{ Natural soil } & & \multicolumn{2}{c}{ Pasteurized soil } \\
\cline { 5 - 6 } Isolate & Shoot wt $(\mathrm{g})$ & Root wt $(\mathrm{g})$ & & Shoot wt $(\mathrm{g})$ & Root wt $(\mathrm{g})$ \\
\hline Control & 0.87 & 0.70 & & 1.09 & 1.15 \\
E22-4 & 0.78 & 0.48 & & 0.78 & 0.25 \\
$5-104$ & 0.59 & 0.34 & & 0.72 & 0.28 \\
CV-B & 0.63 & 0.33 & & 0.71 & 0.30 \\
LSD $(P=0.05)$ & 0.21 & 0.16 & & 0.17 & 0.15 \\
\hline
\end{tabular}

TABLE 5. Effect of Rhizoctonia solani anastomosis group (AG) 5 isolates E22-4 and 5-104 and AG 6 isolate CV-B on growth of 12-week-old apple ('Gala') transplants

\begin{tabular}{lccccc}
\hline & \multicolumn{2}{c}{ Natural soil } & & \multicolumn{2}{c}{ Pasteurized soil } \\
\cline { 2 - 3 } \cline { 5 - 6 } Isolate & Shoot wt $(\mathrm{g})$ & Root wt $(\mathrm{g})$ & & Shoot wt $(\mathrm{g})$ & Root wt $(\mathrm{g})$ \\
\hline Control & 1.99 & 0.96 & & 2.24 & 1.73 \\
E22-4 & 1.62 & 0.79 & & 1.65 & 0.61 \\
$5-104$ & 1.40 & 0.35 & & 1.22 & 0.44 \\
CV-B & 1.37 & 0.38 & & 1.42 & 0.42 \\
LSD $(P=0.05)$ & 0.36 & 0.27 & & 0.46 & 0.32 \\
\hline
\end{tabular}


$\mathrm{CV}$ orchard were identified as AG 6. Isolates from both AG 5 and AG 6 were aggressive pathogens causing severe root rot and ultimately death of apple transplants regardless of plant age at the time of exposure to the pathogen.

The AGs of $R$. solani isolated from apple are rather unusual, as AG 5 has been reported to be weakly virulent relative to other AGs on several plant hosts $(3,28,33)$, and isolates from AG 6 have not been considered to be plant pathogens (28) or only weakly virulent (16). Because the preliminary identification in hyphal anastomosis tests of certain $R$. solani isolates from apple as AG 6 was unexpected, and members of AG 6 are known to anastomose with isolates from AG 8, AG BI, and AG-F at low frequency (28), sequence analysis of the ITS region and restriction analysis of an amplified region of the 28S rRNA gene were conducted to verify initial findings. Within an AG of $R$. solani, sequence identity in ITS 1 was greater than $90 \%$, while sequence identity between AGs ranged from 60 to $80 \%$ (20; M. Mazzola, unpublished data). The ITS 1 sequence from CV-B possessed greater than $90 \%$ identity with the corresponding sequence from a tester strain of AG 6 . Likewise, the restriction pattern obtained by digestion of the amplified fragment of rDNA from isolates CV-B and CV-D with HpaII was identical to that for a known isolate of AG 6, but different from that of any other $R$. solani AG tested. Both of these analyses supported the original determination that these isolates belong to AG 6 . Thus, the results of this study demonstrate that isolates of $R$. solani AG 6 do not simply exist as saprophytes, but can be severe pathogens on certain plant species.

$R$. solani isolates CV-B, E22-4, and 5-104 caused similar damage to 7- or 12-week-old apple seedlings when pathogenicity assays were conducted in pasteurized soil. However, isolates CV-B and 5-104, but not isolate E22-4, caused significant reductions in plant growth when assays were conducted in natural WSL from the DR orchard. DR orchard soil contained isolates of $R$. solani, Pythium ultimum, Phytophthora cactorum, and Cylindrocarpon spp. that were pathogenic to apple (M. Mazzola and F. Martin, unpublished data). In assays to examine the pathogenicity of Rhizoctonia spp., these fungal pathogens caused extensive damage to apple transplants in noninfested WSL, making it difficult to assess the relative contribution of isolate E22-4 to the root disease observed in these tests. These findings could also indicate that isolate E22-4 is a less capable rhizosphere colonist relative to isolates CV-B and 5-104 in competition with the indigenous soil microflora.

Binucleate Rhizoctonia spp. are known to form diverse plant associations ranging from symbiotic, the case with $R$. repens, which forms mycorrhizal associations with orchids $(6,31)$, to pathogenic, as is the case for $R$. cerealis, which causes sharp eyespot of wheat (17). Isolates of binucleate Rhizoctonia spp. recovered from apple roots or orchard soil were diverse both in their effect on apple seedling growth and in anastomosis grouping. The effect of binucleate Rhizoctonia spp. recovered in this study on growth of apple was isolate-specific and ranged from beneficial to deleterious. However, as observed for binucleate Rhizoctonia spp. on other plant hosts $(11,28,33)$, the majority of isolates were avirulent on apple. Binucleate Rhizoctonia spp. isolated from apple represented five known AGs, AG-A, -G, -I, -J, and -Q, and at least two additional Rhizoctonia-like groups that did not anastomose with any tester isolates used in this study. Isolates that were pathogenic to apple belonged to AG-G, -Q, and -I, but not all isolates from these AGs caused root rot of apple in growth chamber experiments at $18^{\circ} \mathrm{C}$. Pathogenic isolates of Rhizoctonia spp. AG-G have been isolated from a number of plant species (28); isolates of AG-I have been reported to cause a root rot of strawberry (18) and AG-Q causes a disease of turf grass (25), but isolates from these AGs have not previously been isolated from apple. The two binucleate Rhizoctonia-like isolates that enhanced growth of apple could not be identified to an AG. However, these isolates appear to be of the same AG, as hyphal anastomosis was observed between the two isolates in agar plate assays and digestion of the amplified rDNA gene fragment for these isolates resulted in identical restriction patterns that were different from all other binucleate Rhizoctonia isolates tested.

The prevalence of binucleate and multinucleate Rhizoctonia spp. cultures from agroecosystems appears to be crop-specific. Binucleate species made up from 5 to $25 \%$ of cultures of Rhizoctonia isolated from sugar beets or associated field soil $(11,23,33)$. Binucleate Rhizoctonia spp. recovered from roots and stems of soybean accounted for less than $5 \%$ of the total population of Rhizoctonia isolated from this host (24). In contrast, binucleate Rhizoctonia spp. represented approximately $65 \%$ of the total collection of Rhizoctonia isolated from apple in this study and composed approximately $50 \%$ of the population of Rhizoctonia spp. recovered from Norway spruce seedlings exhibiting root dieback symptoms in Finland (12). R. solani was isolated infrequently from strawberry in comparison with binucleate Rhizoctonia spp., with isolates from AG-A, -G, and -I representing approximately $90 \%$ of the Rhizoctonia population recovered from this host (18).

Cubeta et al. (5) were able to consistently differentiate 13 of 21 binucleate Rhizoctonia AGs by restriction analysis of PCR-amplified rDNA. Using the same primers and restriction enzymes in this study, isolates of AG-A and AG-G isolated from apple produced the same restriction patterns as the tester strains for these AGs. However, isolates of AG-I, -J, and -Q from apple produced different restriction patterns than were observed for the tester strains, as did isolates of AG-I from different orchards. These findings point to the inherent level of genetic diversity present among isolates of Rhizoctonia spp. within AGs and the potential problems associated with the development of molecular markers for the specific and consistent identification of such a genetically diverse population.

Apple replant disease has been attributed to a variety of biotic and abiotic factors including nematodes, bacteria, fungi, heavy metal contamination, and soil physical properties among others (29). Although numerous fungi have been implicated in this disease phenomenon, there has only been passing mention of the possible role of Rhizoctonia spp. in the etiology of apple replant disease. In a histological study of apple roots from trees exhibiting symptoms of replant disease, Caruso et al. (4) observed hyphae of Rhizoctonia, but there were no attempts to isolate the fungus and assess its pathogenicity on apple. It was suggested that $R$. solani might be involved in nonspecific apple replant problems in New York (2). In the current study, pasteurization of soil from either the $\mathrm{CV}$ or DR orchard resulted in significant improvements in plant growth, and growth of apple in pasteurized soil was equivalent to that obtained in previously unplanted soil from the same site (M. Mazzola, unpublished data), indicating that a replant problem existed at these sites. $R$. solani was only isolated from the roots of severely stunted trees in the recently planted block in the DR orchard and was not isolated from any healthy trees at this site. All of these isolates were pathogenic to apple in growth chamber experiments, causing extensive root rot and tree death. These results suggest that $R$. solani can contribute to the death of young trees in newly established orchards, and studies are in progress to further clarify the role of $R$. solani in apple replant disease.

\section{ACKNOWLEDGMENTS}

I thank M. A. Cubeta and J. M. Raaijmakers for critical review of this manuscript, and S. K. Ivanov and E. L. Valdez for excellent technical assistance.

\section{LITERATURE CITED}

1. Alfieri, S. A., Jr., Langdon, K. R., Wehlburg, C., and Kimbrough, J. W. 1984. Index of Plant Diseases in Florida. Fla. Dep. Agric. Consum. Serv. Div. Plant Ind. Bull. 11.

2. Burr, T. J., Hunter, J. E., Ogawa, J. M., and Abawi, G. S. 1978. A root rot of apple caused by Rhizoctonia solani in New York nurseries. Plant Dis. Rep. 62:476-479. 
3. Carling, D. E., and Leiner, R. H. 1990. Effect of temperature on virulence of Rhizoctonia solani and other Rhizoctonia on potato. Phytopathology 80:930-934.

4. Caruso, F. L., Neubauer, B. F., and Begin, M. D. 1989. A histological study of apple roots affected by replant disease. Can. J. Bot. 67:742-749.

5. Cubeta, M. A., Echandi, E., Abernethy, T., and Vilgalys, R. 1991. Characterization of anastomosis groups of binucleate Rhizoctonia species using restriction analysis of an amplified ribosomal RNA gene. Phytopathology 81:1395-1400.

6. Currah, R. S., Sigler, L., and Hambleton, S. 1987. New records and new taxa of fungi from mycorrhizae of terrestrial orchids of Alberta. Can. J. Bot. 65:2473-2482.

7. Farr, D. F., Bills, G. F., Chamuris, G. P., and Rossman, A. Y. 1989. Fungi on Plants and Plant Products in the United States. The American Phytopathological Society, St. Paul, MN.

8. French, A. M. 1987. California Plant Disease Host Index. Part 1: Fruit and Nuts. California Department of Food and Agriculture, Sacramento.

9. Hepting, G. H. 1971. Diseases of Forest and Shade Trees of the United States. U.S. Dep. Agric. For. Serv. Handbook 386.

10. Herr, L. J. 1979. Practical nuclear staining procedures for Rhizoctonialike fungi. Phytopathology 69:958-961.

11. Herr, L. J., and Roberts, D. L. 1980. Characterization of Rhizoctonia populations obtained from sugarbeet fields with differing soil textures. Phytopathology 70:476-480.

12. Hietala, A. M. 1995. Uni- and binucleate Rhizoctonia spp. co-existing on the roots of Norway-spruce seedlings suffering from dieback. Eur. J. For. Pathol. 25:136-144.

13. Hine, R. B. 1961. The role of fungi in the peach replant problem. Plant Dis. Rep. 45:462-465.

14. Jones, R. W., and Pettit, R. E. 1987. Variation in sensitivity among anastomosis groups of Rhizoctonia solani to the antibiotic gliotoxin. Plant Dis. 71:34-36.

15. Kataria, H. R., Hugelshofer, U., and Gisi, U. 1991. Sensitivity of Rhizoctonia species to different fungicides. Plant Pathol. 40:203-211.

16. Kuninaga, S., Yokosawa, R., and Ogoshi, A. 1979. Some properties of anastomosis group 6 and BI in Rhizoctonia solani Kühn. Ann. Phytopathol. Soc. Jpn. 45:207-214.

17. Lipps, P. E., and Herr, L. J. 1982. Etiology of Rhizoctonia cerealis in sharp eyespot of wheat. Phytopathology 72:1574-1577.

18. Martin, S. B. 1988. Identification, isolation frequency, and pathogenicity of anastomosis groups of binucleate Rhizoctonia spp. from strawberry roots. Phytopathology 78:379-384.

19. Mazzola, M. 1996. Classification and pathogenicity of Rhizoctonia spp. isolated from apple roots and orchard soil. (Abstr.) Phytopathology 86:S5.

20. Mazzola, M., Smiley, R. W., Rovira, A. D., and Cook, R. J. 1996. Characterization of Rhizoctonia isolates, disease occurrence and management in cereals. Pages 259-267 in: Rhizoctonia Species: Taxonomy, Molecular Biology, Ecology, Pathology and Control. B. Sneh, S. Jabaji-Hare, S. Neate, and G. Dijst, eds. Kluwer Academic Publishers, Dordrecht, the Netherlands.

21. Mazzola, M., Wong, O. T., and Cook, R. J. 1996. Virulence of Rhizoctonia oryzae and $R$. solani AG-8 on wheat and detection of $R$. oryzae in plant tissue by PCR. Phytopathology 86:354-360.

22. Mircetich, S. M., and Zentmyer, G. A. 1964. Rhizoctonia seed and root rot of avocado. Phytopathology 54:211-213.

23. Naito, S., Sugimoto, T., Yamaguchi, T., and Fujisawa, I. 1975. Anastomosis groups of Rhizoctonia solani Kühn isolated from diseased sugar beet seedlings. Res. Bull. Hokkaido Natl. Agric. Exp. Stn. 111:25-35.

24. Nelson, B., Helms, T., Christianson, T., and Kural, I. 1996. Characterization and pathogenicity of Rhizoctonia from soybean. Plant Dis. 80:74-80.

25. Oniki, M., Kobayashi, K., Araki, T., and Ogoshi, A. 1986. A new disease of turf-grass caused by binucleate Rhizoctonia AG-Q. Ann. Phytopathol. Soc. Jpn. 52:850-853.

26. Parmeter, J. R., Jr., Sherwood, R. T., and Platt, W. D. 1969. Anastomosis grouping among isolates of Thanatephorus cucumeris. Phytopathology 59:1270-1278

27. Smiley, R. W., Wilkins, D. E., and Klepper, E. L. 1990. Impact of fungicide seed treatments on Rhizoctonia root rot, take-all, eyespot, and growth of winter wheat. Plant Dis. 74:782-787.

28. Sneh, B., Burpee, L., and Ogoshi, A. 1991. Identification of Rhizoctonia species. The American Phytopathological Society, St. Paul, MN.

29. Traquair, J. A. 1984. Etiology and control of replant problems: A review. Can. J. Plant Pathol. 6:54-62.

30. Vilgalys, R., and Hester, M. 1990. Rapid genetic identification and mapping of enzymatically amplified ribosomal DNA from several Cryptococcus species. J. Bacteriol. 172:4238-4246.

31. Warcup, J. H. 1981. The mycorrhizal relationships of Australian orchids. New Phytol. 87:371-381.

32. White, T. J., Bruns, T., Lee, S., and Taylor, J. 1990. Amplification and direct sequencing of fungal ribosomal RNA genes for phylogenetics. Pages 315-322 in: PCR Protocols: A Guide to Methods and Applications. M. A. Innis, D. H. Gelfand, J. J. Sninsky, and T. J. White, eds. Academic Press, San Diego, CA.

33. Windels, C. E., and Nabben, D. J. 1989. Characterization and pathogenicity of anastomosis groups of Rhizoctonia solani isolated from Beta vulgaris. Phytopathology 79:83-88. 